teems to lead the picking up of strains which are resistant to most of the antibiotics.

These findings once again stress the emergence of multi drug resistant strains due to indiscriminate use of antimicrobials especially by generäl practitioners. Infect antibiotics should be used only in fulminent diarrheas and invasive Samonellosis after obtaining the antibiogram pattern. Mild to moderate diarrheas being self limiting and should not be treated with antimicrobials.

\section{REFERENCES}

1. Edwards $P R$ and Ewing WH. Identification of Enterobactriaceae. 3rd ed. Minneapolis, Burgese Publishing Co., 1972

2. Bauer AW, Kirby WMM, Sherris JC and Truck $M$. Antibiotic susceptibility testing by standardized single disc method. Am J Clin Pathol 1966; 45 : 493-496.

3. Fule RP and Kaundinya DV. Isolation of Salmonella from acute diarrhoea patients in Ambajogai rural area Indian J Med Res 1985; 82 : 276-280.

4. Shoha R, Khurana S. Vadhera DV and Sharme S. Bioecological factors and Salmonella diarrhoea. Indian J Med Res 1987; 86 : 441-450.

5. Gonies TAT, Rassi V, Mac Donald KL et al. Enteropathogens associated with acute diarrheal disease in urban infants in Saopaulo, Brazil, J Infect Dis 1991; 14 : 331-337.

6. Paul SS, Pawa RR, Verma $M$ and Singh $D$. Out break of Salmonella infection in a paediatric department. Indian Paediatr $1981 ; 18$ : 899-901.

\title{
TOWARDS A SINGLE VACCINE FOR CHILDREN
}

Every year, eight million children die in developing countries from viral and bacterial diseases, and 900 million are severeiy ill. Viral diseases which kill more than three million children every year include measles ( 1.5 million deaths) : rotaviral enteritis $(800,000$ deaths) : Poliomyelitis; hepatitis $\mathrm{A}$ and $\mathrm{E}$ : denoue (30-60) million infections) : with 10,000 deaths) and acute respiratory viral diseases.

Bacterial diseases, resulting in the death of over five million children a year, include tetanus $(800,000$ newborn infants) : meningococcal meningitis : bacterial diarthoeal diseases (more than 1.6 million deaths from shioella, Cholera. Escherichia coli and typhoid) : pneumococcal pneumonia (the leading cause of death from acute respiratory illness) : and tuberculosis, which infects both children and adults (over 2.5 million deaths).

These tragedies could be largely prevented by new and improved vaccines, and the international community is joining forces to make this a reality in the 1990s. In 1984 the WHO/UNDP Origranne fir Vaccine Development (PVD) was created to coordinate international efforts with academic institutions or with other scientific groups. In 1991. The Children's Vaccine Initiative was iaunched to intensify those efforts.

Research using a wide range of techniques is being carried out with a visionary goal in mindthat of perfecting a "Children's vaccine", a one-shot multiple vaccine, preferably given orally, which would protect every child for life against all important infectious diseases. Such an advance would simplify vaccine programmes in developing countries and help to save millions of children from sickness and death. 